\title{
AKUNTABILITAS DALAM PERSPEKTIF AJARAN KARMA PHALA SEBAGAI PEDOMAN UNTUK MEMBANGUN KARAKTER AUDITOR
}

\author{
Ida Ayu Budhananda Munidewi ${ }^{1}$ \\ ${ }^{1}$ Fakultas Ekonomi dan Bisnis, Universitas Mahasaraswati Denpasar, Bali, Indonesia \\ email : budhananda1990@gmail.com
}

\begin{abstract}
ABSTRAK
Akuntabilitas auditor terdiri dari aspek-aspek yaitu motivasi, kewajiban sosial dan pengabdian pada profesi. Ketiga aspek ini harus dimiliki oleh auditor untuk dapat menghasilkan audit yang berkualitas. Dalam ajaran agama Hindu, dikenal adanya ajaran hukum karma phala atau sebab akibat. Dengan latar belakang ini penelitian ini mengkaji akuntabilitas auditor dalam perspektif ajaran karma phala. Penelitian ini menggunakan metode kualitatif yang menitikberatkan pada deskriptif dan interpretasi pada perilaku manusia. Data penelitian ini diperoleh melalui observasi partisipatif dan wawancara tidak terstruktur. Analisis data melalui tiga tahapan yaitu reduksi data, penyajian data dan penarikan kesimpulan. Hasil penelitian menunjukkan bahwa ajaran karma phala sebenarnya telah melekat dalam setiap aspek akuntabilitas auditor, hanya saja diperlukan penekanan yang lebih terhadap penyadaran peran auditor di masyarakat dan terhadap profesinya.
\end{abstract}

Kata kunci: Akuntabilitas auditor, hukum karma phala, karakter auditor

\section{THE ACCOUNTABILITY OF KARMA PHALA DOCTRINE PERSPECTIVE AS A GUIDELINE TO BUILD AUDITORS' CHARACTER}

\begin{abstract}
Auditor's accountability consists of aspects such as motivation, social obligations and dedication to profession. These three aspects must be owned by the auditor to be able to produce a good audit quality.Hindu's society recognize the legal doctrine of karma phala or causal. Due to the reason, this purpose study is to examine the accountability of auditors in the perspective of karma phala. This study used a qualitative method that focuses on the descriptive and the interpretative of human behaviour. The research data was obtained through participant observation and unstructured interview. Data analyze through three stages: data reduction, data presentation and conclusion. The result shows that karma phala actually been embedded in every aspect of auditor's accountability, but need more emphasis on awareness of the role of auditors in the public and the profession.
\end{abstract}

Keywords: Auditor accountability, karma phala, auditor's character DOI: https://doi.org/10.24843/JIAB.2017.v12.i01.p07

\section{PENDAHULUAN}

Profesi pemeriksa laporan keuangan atau lebih sering disebut auditor tidak luput dari tantangan dalam menjalankan pekerjaannya. Tantangan yang harus dijalani dan dibarengi dengan keterikatan tanggung jawab profesi sebagaimana panduan standar teknis dituangkan dalam Standar Profesional Akuntan Publik (SPAP). SPAP di Indonesia mengacu pada International Standards on Auditing (ISA).

SPAP SA 700 menjelaskan tanggung jawab auditor dalam paragraf Laporan Auditor Independen (LAI) “Tanggung jawab kami adalah untuk menyatakan suatu opini atas laporan keuangan tersebut berdasarkan audit kami." Setiap audit yang dilakukan oleh auditor melibatkan prosedurprosedur untuk memperoleh bukti audit baik secara kuantitatif (berupa angka-angka) dan kualitatif (pengungkapan) pada laporan keuangan. Standar mengharuskan auditor patuh pada ketentuan etika serta merencakan dan melaksanakan audit untuk mendapat keyakinan memadai atas laporan keuangan. Penilaian risiko dalam melakukan audit menjadi suatu hal yang wajib bagi auditor untuk mengetahui apakah ada kesalahan penyajian yang material dalam laporan keuangan baik disebabkan oleh kecurangan atau kesalahan. Dengan demikian auditor memiliki tanggung jawab mulai dari proses pengumpulan bukti-bukti audit, penilaian risiko, pengevaluasian kebijakan yang merupakan pertimbangan dasar dalam merumuskan opini.

Dalam akuntansi modern, seperti yang dikutip Sukoharsono (1998) dari Roslender, menyatakan bahwa "modern accountancy is a highly relevant subject for study at present time. Having designated it as an institution... In this way accountancy is 
being seen as the equivalent of the major social institutions such as the family, religion, work, education, art, literature, science, and technology." Pernyataan dari Roslender tersebut menunjukkan bahwa akuntansi sarat akan nilai untuk mengokohkan nilai-nilai yang ada di masyarakat sehingga akuntabilitas individu dapat diwujudkan, terutama untuk menunjang peran auditor dalam pelaksanaan audit.

Akuntabilitas atau tanggung jawab auditor merupakan faktor paling penting dalam menentukan kualitas audit, dimana akuntabilitas yang dimiliki oleh auditor dapat meningkatkan proses kognitif dalam pengambilan keputusan (Messier dan Quilliam, 1992). Keputusan yang diambil oleh auditor agar menghasilkan audit yang berkualitas selain berdasarkan akuntabilitas juga dilatarbelakangi oleh independensi dan sikap kehati-hatian. Syarat utama dalam mewujudkan akuntabilitas adalah berada pada situasi dan kondisi lingkungan yang mengutamakan keterbukaan sebagai landasan pertanggungjawaban serta lingkungan yang demokratis dalam menyampaikan pendapat, saran, kritik, maupun argumentasi terhadap perbaikan kondisi kinerja atau kegiatan yang lebih baik dan terarah (Ilmiyati dan Suhardjo, 2012).

Skandal keuangan yang terjadi belakangan ini baik terjadi di dalam maupun luar negeri sempat membuat kepercayaan masyarakat pada profesi akuntan publik umumnya dan auditor khususnya menjadi menurun. Contoh kasus yang pernah terjadi menimpa kantor akuntan publik Drs. Thomas Iguna yang melakukan pemeriksaan atas laporan keuangan PT. Bank Global Internasional Tbk. Ijin KAP Drs. Thomas Iguna dibekukan oleh Menteri Keuangan dengan Keputusan Menteri Keuangan Nomor 132/ KM.1/2008 tertanggal 26 Februari 2008 selama 12 bulan (Tempo, 31 Maret 2008). Pembekuan ijin ini dikarenakan KAP Drs. Thomas Iguna melanggar Standar Auditing (SA) dan Standar Profesional Akuntan Publik (SPAP) ketika melakukan audit di Bank Global. Sejak saat itu KAP dan auditor dilarang memberikan jasa audit lainnya serta jasa yang berkaitan dengan akuntansi, keuangan, manajemen, kompilasi, perpajakan, dan konsultasi sesuai kompetensi Akuntan Publik (AP) dan peraturan perundang-undangan yang berlaku.

Menurunnya kepercayaan masyarakat terhadap profesi auditor karena ketidaksesuaian harapan publik terhadap kualitas audit yang dihasilkan. Auditor yang seharusnya sebagai pihak independen memberikan keyakinan terhadap keandalan sebuah laporan keuangan. Kualitas hasil pekerjaan auditor dapat dipengaruhi rasa akuntabilitas yang dimiliki auditor dalam menyelesaikan pekerjaan audit (Mardisar \& Sari, 2007). Elisha dan Icuk (2010) meneliti tentang akuntabilitas yang dilihat dari tiga aspek yaitu motivasi, pengabdian pada profesi dan kewajiban sosial. Tiga aspek ini dapat berpengaruh terhadap kualitas audit.

Penelitian di Indonesia mengenai akuntabilitas auditor telah banyak dilakukan, namun sangat jarang melihat penerapan akuntabilitas auditor melalui kaca mata nilai kearifan lokal. Penelitian ini melihat akuntabilitas atau tanggung jawab auditor melalui perspektif Hukum Karma Phala, yang merupakan salah satu dari lima keyakinan (Panca Sradha) dari agama Hindu. Karma Phala berasal dari dua kata yaitu karma dan phala, dimana karma berarti perbuatan atau aksi dan phala berarti buah atau hasil. Jadi, karma phala berarti buah dari perbuatan, baik yang akan dilakukan maupun yang akan dilakukan. Dalam keyakinan agama Hindu, Hukum Karma Phala memberikan optimisme kepada setiap manusia bahkan semua mahluk hidup untuk yakin bahwa semua perbuatan akan mendatangkan hasil. Apapun yang kita perbuat, seperti itulah hasil yang akan kita terima. Umat Hindu meyakini bahwa yang menerima adalah yang berbuat dan efeknya kepada orang lain. Menurut kitab suci Bradh Aranyaka Upanisad, hukum diartikan sama dengan kebenaran.

Perspektif hukum Karma Phala dipilih dalam penelitian ini karena ajaran karma phala telah melekat dalam kehidupan umat Hindu di Bali. Nilai-nilai ajaran karma phala ini telah diajarkan ketika seseorang berada dalam lingkup keluarga kemudian saat menjalankan masa Brahmacari (masa menuntut ilmu), dan saat terjun ke masyarakat. Ajaran karma phala kemudian menjadi sebuah landasan sikap batin umat Hindu, dimana umat Hindu percaya bahwa setiap kegiatan dalam kehidupan ini baik dalam pemikiran dan perencanaan, kata-kata dan pelaksanaan apabila dibarengi oleh sikap bathin Adharma (tidak baik) walaupun masih dalam tahap perencanaan, yang bersangkutan sudah pasti akan membawa suatu akibat buruk, diminta atau tidak, cepat atau lambat dan dirasa atau tidak, akan muncul dengan sendirinya. Karma Phala sebagai ajaran dasar pengendalian diri merupakan ajaran pokok untuk memperbaiki moral dan etika manusia dalam kehidupan bermasyarakat. Dengan memahami hakekat tentang Karma phala, maka manusia tidak akan mungkin untuk melakukan perbuatan-perbuatan tercela yang jelas-jelas keluar dari ajaran agama dan menyebabkan kerugian, kehancuran bagi orang lain.Seperti tersirat di dalam Sarasamuccaya Sloka 3 , yang artinya "menjelma menjadi manusia itu adalah sungguh-sungguh utama, sebabnya demikian, karena 
ia dapat menolong dirinya dari keadaan sengsara (lahir dan mati berulang-ulang) dengan jalan berbuat baik, demikianlah keuntungannya dapat menjelma menjadi manusia”.

Auditor adalah manusia yang melakukan karya. Tanggung jawab auditor terletak pada pernyataan opini terhadap kewajaran suatu laporan keuangan entitas yang diauditnya. Penyelesaian tanggung jawab auditor tersebut dilatarbelakangi oleh kompetensi dan independensi yang dimiliki oleh auditor. Penerapan kompetensi dan independensi ini tidak terlepas dari keterkaitan etika di dalamnya. Akuntan mempunyai kewajiban untuk menjaga standar perilaku etis tertinggi kepada organisasi tempat mereka bernaung, profesi mereka, masyarakat dan diri mereka sendiri, dimana akuntan mempunyai tanggung jawab menjadi kompeten dan menjaga integritas dan objektivitas mereka (Nugrahaningsih, 2005).

Implementasi standar audit sebagai bentuk tanggung jawab auditor harus dibarengi oleh keyakinan auditor dalam menyelesaikan setiap pekerjaan audit dan memikirkan konsekuensinya sebelum memberikan penilaian atas laporan keuangan entitas yang diaudit. Oleh karena itu, penelitian ini ingin mendalami sejauh mana auditor memahami tanggung jawabnya dilihat dari perspektif hukum karma phala. Melalui penelitian ini dapat memberikan refleksi mengenai tanggung jawab auditor berlandaskan sikap batin yang terkandung dalam ajaran hukum karma phala sebagai hukum sebab akibat yang dipedomani oleh masyarakat Hindu di Bali sebagai kebenaran yang universal.

Memahami tanggung jawab auditor dalam melaksanakan tugasnya tidak hanya dapat dilihat dari standar audit dan prinsip-prinsip etika yang telah dilaksanakannya, tetapi pemahaman tersebut berasal dari diri auditor dimana menyadari atau tidak apa yang diperbuatnya. Ajaran karma phala menjadi pedoman yang digunakan oleh peneliti untuk melihat implementasi tanggung jawab auditor. Oleh karena itu, yang menjadi pertanyaan dalam penelitian ini adalah: "Bagaimana auditor memandang tanggung jawabnya dilihat dari perspektif ajaran karma phala?"

Penelitian ini bertujuan untuk mendapatkan pemahaman yang mendalam mengenai tanggung jawab auditor melalui perspektif ajaran karma phala. Melalui penelitian ini, auditor dapat memahami tanggung jawabnya sebagai profesi yang disoroti masyarakat dan masyarakat memiliki ekspektasi tinggi terhadap profesi auditor, sehingga dalam melaksanakan tugasnya auditor harus selalu memikirkan konsekuensi atas setiap pekerjaan dan keputusan yang diambilnya.
Tanggung jawab auditor atau akuntabilitas seperti yang didefinisikan oleh Tetlock (1984) sebagai bentuk dorongan psikologi yang membuat seseorang berusaha mempertanggungjawabkan atas tindakan dan keputusan yang diambil. Elisha dan Icuk (2010) menggunakan tiga indikator untuk mengukur tanggung jawab auditor, dilihat dari motivasi, pengabdian pada profesi dan kewajiban sosial. a) Motivasi dapat diartikan sebagai sebuah kecenderungan yang ada di dalam diri seseorang yang membangkitkan topangan dan mengarahkan tindak-tanduknya. Robins (2008) menyatakan bahwa motivasi merupakan kekuatan yang besar yang dapat mendorong seseorang untuk dapat mencapai sesuatu sasaran atau tujuan yang telah ditetapkan. Semakin kuat motivasi seseorang maka akan semakin mudah untuk mendapatkan apa yang diinginkan. Apabila dikaitkan dengan pekerjaan, motivasi yang berasal dari internal atau eksternal seseorang digunakan untuk melakukan pekerjaan disertai semangat yang tinggi dengan menggunakan kemampuan dan keahlian yang dimilikinya. Auditor yang memiliki motivasi dalam bekerja, maka auditor tersebut dilatarbelakangi oleh intensitas, arah dan ketekunan sehingga tujuan dari organisasi dapat tercapai. Kaitan motivasi dan akuntabilitas, auditor yang memiliki akuntabilitas yang tinggi juga memiliki motivasi tinggi dalam setiap penugasan audit yang dilakukannya. b) pengabdian pada profesi. Pengabdian lekat dengan kesetiaan, komitmen dan pengorbanan. Makna yang terkandung dalam pengabdian pada profesi adalah kesetiaan pada profesi, penuh tanggung jawab dan siap berkorban demi pengabdian pada profesi. Seseorang yang profesional adalah orang yang memiliki loyalitas pada profesi, tanpa adanya loyalitas seseorang tidak dapat dikatakan profesional, dan sebaliknya tanpa adanya loyalitas pada profesi bagaimana seseorang bisa menguasai bidang profesinya dengan baik. Pengabdian pada profesi akan berpengaruh besar pada peningkatan kemampuan walau terkadang imbalan ekstrinsik kurang. Sikap mengabdi pada profesi dapat dikatakan sebagai bentuk pencurahan diri yang total dalam pekerjaan, dimana pekerjaan menjadi tujuan tidak hanya sebagai alat mencapai tujuan. Auditor yang bekerja penuh dengan totalitas merupakan hasil komitmen dengan dirinya, sehingga harapan yang diinginkan adalah kepuasan rohani yang disusul kepuasan materi. c) Kewajiban sosial. Kewajiban sosial merupakan pandangan mengenai pentingnya peranan profesi dan manfaat yang diperoleh baik oleh masyarakat maupun profesional karena adanya pekerjaan tersebut (Rendy, 2007). 
Apabila seorang auditor menyadari betapa besarnya perannya bagi masyarakat dan profesinya, maka ia akan memiliki sebuah keyakinan bahwa dengan melakukan pekerjaan dengan sabaik-baiknya, maka ia akan memberikan kontribusi yang sangat besar bagi masyarakat dan profesinya tersebut. Maka ia akan merasa berkewajiban untuk memberikan yang terbaik bagi masyarakat dan profesinya, hal ini disebut sebagai kewajiban sosial (Elisha dan Icuk, 2010).

Kitab Dharmasastra yang memuat bidang hukum Hindu tertua dan sebagai sumber hukum Hindu yang paling terkenal adalah Manawa Dharmasastra. Berbagai bidang hukum Hindu yang termuat dalam Kitab Manawa Dharmasastra adalah sebagai berikut: (1) bidang hukum keagamaan; (2) bidang hukum kemasyarakatan; (3) bidang hukum tata negara. Hukum Hindu (Dharmasastra) dituliskan secara utuh dalam kitab Manawa Dharmasastra yang selanjutnya digunakan sebagai sumber hukum Hindu guna menata umat Hindu mewujudkan moksartham jagadhita ya ca iti dharma (sejahtera dan bahagia) lahir batin.

Dalam ajaran agama Hindu, memaparkan adanya dua hukum yang berlaku dalam alam semesta ini yaitu hukum Rta (hukum yang mengatur dinamika alam semesta, benda dan materi) dan hukum karma (hukum yang mengatur dinamika kehidupan para mahluk di dunia). Hukum karma termasuk ke dalam bidang hukum keagamaan. Karma berasal dari bahasa Sansekerta yang berarti perbuatan kerja atau gerak. Perbuatan (karma) meninggalkan jejak-jejak perbuatan (karma vasana) yang suatu saat nanti akan muncul sebagai Karma phala (hasil perbuatan) yang akan menentukan baik-buruk perjalanan kehidupan manusia. Jika karma kita baik (subha karma) maka akan mendapatkan perjalanan hidup yang lancar dan bahagia. Apabila karma kita tidak baik (asubha karma) maka akan mendapatkan pengalaman hidup yang berat dan sengsara. Klasifikasi baik dan buruk hanya diberikan oleh manusia sebab hanya manusialah yang mampu membedakan antara yang baik dan buruk.

Karma phala juga terkandung dalam kutipan sloka-sloka Sarasamuccaya, dimana kitab suci ini mengungkapkan:

Manusah sarvabhutesu varttate vai subhasubhe Asubhesu samavistam subhesvevavakarayet (Sarasamuccaya. 2)

Risakwehning sarwa bhuta, iking janma wwang juga wenang gumawayaken ikang subhasubha karma, kuneng panentasakna ring subhakarma juga ikangasubhakarma, phalaning dadi wwang.

Artinya:

Diantara semua mahluk hidup, hanya yang dilahirkan menjadi manusia sajalah, yang dapat melakukan perbaikan baik dan perbuatan buruk, leburlah ke dalam perbuatan baik, segala perbuatan yang buruk itu; demikianlah gunanya (pahalanya) menjadi manusia.

Umat Hindu percaya bahwa dengan berbuat baik (Subha karma) adalah cara untuk melepaskan diri dari keadaan samsara (punarbhawa) atau kelahiran kembali. Jadi apabila semasa hidupnya banyak berbuat baik, maka kelahiran berikutnya akan meningkat kualitasnya. Demikian juga bila semasa hidupnya banyak berbuat dosa maka kelahiran berikutnya akan menurun kualitasnya, bahkan tidak menutup kemungkinan akan terlahir sebagai binatang atau tumbuhan.

Tiga macam karma jika dilihat dari segi waktu hasil karma seseorang maka dapat digolongkan menjadi tiga macam, yaitu a) Sanchita karma adalah karma atau perbuatan yang dilakukan pada masa hidup di dunia, baru akan menerima pahalanya setelah meninggal dunia. b) Prarabdha karma adalah karma atau perbuatan seseorang yang pahalanya langsung diterima pada kehidupan ini. c) Kryamana karma adalah pahala yang diterima seseorang pada kehidupan ini atas hasil dari perbuatan (karmanya pada kehidupan yang lampau).

Meskipun jenis-jenis karma digolongkan seperti diatas, tetapi dalam kenyataan sangat sulit mengidentifikasi setiap karma yang kita terima saat ini. Mengenai kapan waktu kita akan menerima pahala merupakan rahasia dari Tuhan Yang Maha Esa. Namun, penting bagi kita untuk mengetahui jenis-jenis karma phala adalah untuk meningkatkan bakti kepada Tuhan Yang Maha Esa. Ajaran hukum karma phala ini menuntun umat Hindu atau yang percaya terhadap adanya hukum ini untuk yakin bahwa apapun yang dialami pada kehidupan ini adalah hasil perbuatan diri sendiri, bukan karena orang lain. Oleh karena itu, penting bagi profesi seperti auditor meyakini adanya hukum karma phala ini untuk dapat melakukan yang terbaik di dunia ini, untuk diri sendiri, masyarakat dan profesinya dengan melaksanakan tanggung jawab sebaik-baiknya, sesuai Kode Etik Profesi Akuntan, sesuai UndangUndang No. 5 tahun 2011 tentang Akuntan Publik dan Standar Profesional Akuntan Publik (SPAP) dalam melaksanakan penugasan audit. 


\section{METODE PENELITIAN}

Penelitian ini menggunakan pendekatan kualitatif (interpretif) yang menitikberatkan pada deskripsi dan interpretasi terhadap perilaku manusia. Peneliti menyadari bahwa setiap individu memiliki keunikan, termasuk individu yang menjadi narasumber dalam penelitian ini dan pendekatan kualitatif merupakan pendekatan yang cocok untuk memahami keunikan masing-masing individu dalam penelitian ini. Pendekatan kualitatif memiliki asumsi bahwa pemahaman tingkah laku manusia itu tidak cukup diperoleh hanya dari surface behavior, tetapi tidak kalah pentingnya adalah inner perspective of human behavior, sebab dari sini akan diperoleh gambaran yang utuh tentang manusia dan dunianya (Ghoni dan Almanshur, 2012). Peneliti menggunakan pendekatan kualitatif karena membutuhkan suatu pemahaman yang detail dan lengkap mengenai bagaimana seorang auditor menyikapi akuntabilitasnya jika bercermin melalui ajaran karma phala yang telah dikenalnya sejak dini. Detail ini hanya dapat diperoleh peneliti dengan berinteraksi dan berbicara langsung dengan auditor serta mendatangi tempat kerja mereka, tanpa diganggu oleh dugaan atau pengharapan dari peneliti melalui literatur yang dibacanya.

Penelitian ini dilakukan di Kantor Akuntan Publik (KAP) BM yang terletak di Denpasar. Alasan dipilihnya kantor akuntan publik ini dikarenakan peneliti telah terlebih dahulu berkecimpung atau memasuki latar sosial dari sasaran penelitian.Sumber data dalam penelitian ini adalah kata-kata dan perilaku serta tindakan yang berasal dari 4 (empat) informan. Informan adalah auditor dimana merupakan orang-orang yang terlibat langsung dalam proses audit mulai dari perencanaan hingga penyelesaian audit. Pemilihan informan berdasarkan lamanya pengalaman dalam audit laporan keuangan. Penelitian ini berlangsung selama dua bulan, dimana peneliti terlibat langsung di dalamnya.

Untuk mencapai tujuan penelitian dengan metode kualitatif, peneliti menggunakan teknik pengumpulan data seperti observasi dan wawancara yang umumnya mutlak digunakan dalam penelitian kualitatif. Penelitian ini menggunakan teknik observasi partisipatif, dimana peneliti terlibat dalam kehidupan dari masyarakat yang diteliti dalam hal ini kehidupan auditor untuk dapat memahami gejalagejala yang ada. Sedangkan teknik wawancara yang digunakan peneliti adalah wawancara tidak terstruktur atau wawancara secara mendalam dan terbuka (open-ended interview). Metode wawancara tidak terstruktur ini bertujuan memperoleh bentuk-bentuk tertentu informasi dari semua informan, tetapi susunan kata dan urutannya disesuaikan dengan ciri-ciri informan (Ghony dan Almanshur, 2012). Teknik pengumpulan data tidak terbatas hanya observasi dan wawancara saja, tetapi peneliti juga melakukan teknik pengumpulan data lain seperti studi dokumen, digunakan demi kelengkapan data terkait tujuan penelitian yang telah ditetapkan.

Analisis data dalam penelitian kualitatif dilakukan melalui pengaturan data secara logis dan sistematis, dan analisis data itu dilakukan sejak awal peneliti terjun ke lokasi penelitian hingga pada akhir penelitian atau pengumpulan data (Ghony dan Almanshur, 2012). Metode analisis data dalam penelitian ini menggunakan langkah-langkah yang dikemukakan oleh Miles dan Huberman (1984), dimana tahapan analisis data dilakukan secara interaktif dan secara terus menerus selama pengumpulan data. Analisis data dalam penelitian ini digambarkan melalui model pada gambar 1 .

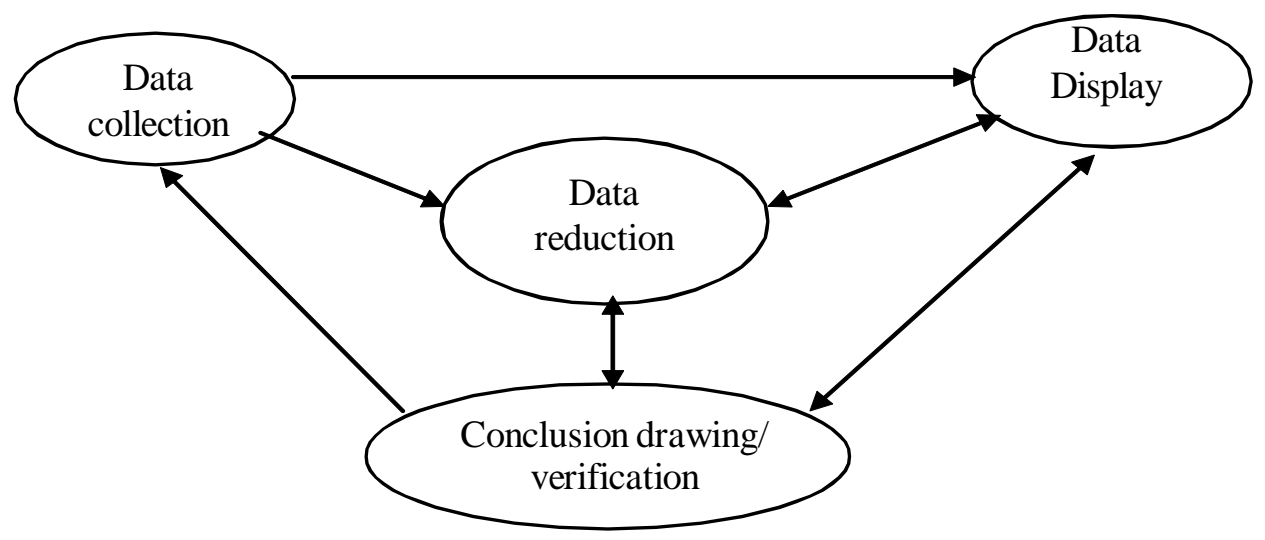

Gambar 1. Model Analisis Data Miles dan Huberman

Sumber: Miles dan Huberman (1984) 
Reduksi data adalah proses pemilihan, pemusatan perhatian pada penyederhanaan, pengabstrakan, dan transformasi data yang muncul dari catatan-catatan tertulis di lapangan. Reduksi data berlangsung terus menerus selama penelitian berlangsung. Langkah selanjutnya adalah data display atau penyajian data yang biasanya berbentuk narasi atau uraian singkat, bagan, hubungan antar kategori, atau flowchart. Tujuan dari penyajian data ini adalah memudahkan peneliti memahami gambaran keseluruhan atas bagian-bagian tertentu dari data yang diperoleh di lapangan. Langkah akhir dari proses analisis data penelitian ini adalah penarikan kesimpulan yang merupakan upaya untuk memperoleh arti dan makna yang mendalam terhadap data yang dikumpulkan dan dianalisis dengan hukum karma phala, sehingga kesimpulan yang didapatkan relevan dengan teori yang ada dan kenyataan yang diperoleh di lapangan (terutama terkait dengan pemahaman hukum karma phala) oleh informan dari KAP BM.

\section{HASIL DAN PEMBAHASAN}

Akuntabilitas auditor dapat dilihat dari tiga aspek utama, yakni motivasi, pengabdian pada profesi dan kewajiban sosial. Profesionalisme auditor akan terwujud jika menerapkan ketiga aspek akuntabilitas tersebut, demikian pula kualitas audit yang baik akan terealisasi jika auditor dalam proses audit dari perencanaan hingga penyelesaian laporan audit hingga pemberian opini atau pendapat dibarengi dengan aspek-aspek akuntabilitas.

Pehamaman auditor mengenai akuntabilitas terbangun melalui pengalaman-pengalaman yang didapatkan dari lamanya bekerja di kantor akuntan publik. Seperti yang disampaikan oleh Made sebagai berikut. "Saya memahami tanggung jawab auditor dari buku yang saya pelajari pada saat kuliah dan didukung pengalaman saya selama menjadi auditor di KAP.”

Akuntabilitas auditor telah diberikan pada saat perkuliahan dalam bentuk penjelasan buku, namun dibutuhkan pengalaman secara langsung untuk dapat memahami secara lebih baik terhadap arti penting akuntabilitas atau tanggung jawab auditor dalam proses audit. Pengalaman akan memberikan gambaran secara nyata mengenai akuntabilitas auditor seutuhnya.

Aspek akuntabilitas salah satunya adalah motivasi. Auditor memiliki motivasi yang beragam dalam melakukan pekerjaannya, seperti yang disampaikan oleh Anton berikut ini. "Sebagai auditor saya memiliki motivasi bekerja untuk memperoleh penghasilan untuk hidup dan berusaha memuaskan klien yang saya tangani."

Hal tersebut senada dengan apa yang disampaikan oleh Sita, bahwa: "Bekerja sebagai auditor tentunya untuk meningkatkan taraf hidup dengan gaji yang didapatkan, selain itu dengan menjadi seorang auditor saya mendapatkan banyak pengalaman bagaimana menangani klien dan menghadapi banyak orang."

Made dan Sita termotivasi bekerja sebagai auditor dikarenakan profesi ini dapat meningkatkan taraf hidup. Pengalaman yang didapatkan ketika bekerja sebagai auditor menjadi motivasi lain bagi Anton dan Sita, terutama bagaimana menghadapi berbagai macam karakteristik klien.

Pendapat yang sedikit berbeda disampaikan oleh Erna mengenai motivasinya bekerja sebagai auditor KAP. "Saya ingin tahu bagaimana proses dan prosedur dalam mengaudit laporan keuangan klien. Selama ini saya sudah mempelajari alur siklus akuntansi sampai menjadi laporan keuangan. Sedangkan kalau audit adalah memeriksa laporan keuangan, buku besar, jurnal umum bahkan sampai bukti-bukti transaksi. Inilah tantangan saya apakah dari laporan keuangan tersebut terdapat kekeliruan pencatatan atau informasi."

Melalui pernyataan Erna tersebut, ia termotivasi bekerja sebagai auditor dikarenakan ingin menguji diri mengenai pemahaman terhadap proses akuntansi dan audit yang telah ia pelajari selama di bangku kuliah. Sebagai auditor Erna merasa tertantang untuk menemukan adanya kekeliruan pencatatan atau penyajian informasi dari laporan keuangan klien yang diaudit.

Tanggung jawab utama auditor untuk menilai kewajaran laporan keuangan dari salah saji secara material yang sesuai dengan prinsip akuntansi yang berlaku umum, standar audit dan kode etik akuntan. Selain menilai kewajaran suatu laporan keuangan, menurut Statement on Auditing Standard (SAS) No. 82 mengenai Consideration of Fraud in a Financial Statement Audit, menyatakan bahwa auditor memiliki tanggung jawab untuk mendeteksi kecurangan dengan merencanakan dan melaksanakan audit untuk memperoleh kepastian mengenai apakah laporan keuangan bebas dari salah saji (misstatement) secara material baik yang disebabkan oleh kesalahan atau kecurangan (AICPA, 1997). Menarik bagi Erna dan auditor yang lainnya menjadikan motivasi untuk menemukan adanya kecurangan yang disengaja maupun tidak untuk meningkatkan kualitas audit.

Motivasi bekerja sebagai auditor tidak hanya mengaplikasikan teori yang sudah pernah didapatkan 
di bangku perkuliahan dan bertemu dengan berbagai macam karakteristik lewat klien. Dapat dikatakan pengalaman yang didapatkan selama bekerja sebagai auditor secara tidak langsung dapat mengasah soft skill dalam hal berdiskusi, berbicara dan bersikap secara profesional.

Hal yang menarik kemudian diugkapkan oleh Erna. "Sebagai auditor juga membuat saya banyak belajar tentang bagaimana cara berdiskusi dengan rekan satu tim dan klien. Di samping itu motivasi saya bekerja sebagai auditor adalah ingin membuka kantor akuntan publik sendiri."

Erna dan auditor lainnya percaya bahwa dengan melakukan usaha-usaha yang terkait dengan tanggung jawab mereka sebagai auditor, maka apa yang diinginkan dapat tercapai sesuai dengan motivasi yang mereka miliki masing-masing. Teori Vroom (1964) dalam Lunenberg (2011) mengenai Cognitive Theory Of Motivation menjelaskan bahwa masyarakat percaya ada hubungan antara usaha yang mereka tunjukkan dalam perusahaan, kinerja dari usaha tersebut dan penghargaan yang mereka terima dari usaha dan kinerja mereka.

Selain motivasi, akuntabilitas auditor ditunjukkan dengan adanya pengabdian pada profesi. Pengabdian pada profesi adalah bentuk pencurahan diri yang total dalam pekerjaan, dimana pekerjaan menjadi suatu tujuan tidak hanya sebagai alat mencapai tujuan. Peneliti kemudian bertanya mengenai apa yang auditor lakukan sebagai salah satu bentuk pengabdian pada profesinya. Sita, auditor yang sudah bekerja selama kurang lebih dua setengah tahun ini kemudian menanggapi.

"Dalam melaksanakan segala prosedur audit, saya melaksanakan dengan penuh tanggung jawab, berdedikasi tinggi dan teliti serta bagaimana saya menghadapi klien dalam berkomunikasi dan menangani klien."

Dedikasi tinggi menjadi penekanan Sita dalam melaksanakan tanggung jawabnya sebagai auditor yang mana merupakan suatu bentuk dari pengabdian terhadap profesi. Auditor juga sangat identik dengan ketelitian dan juga kehati-hatian (due care) yang telah dijabarkan dalam Kode Etik Profesi Akuntansi Indonesia.

Terkait dengan akuntabilitas auditor, pengabdian pada profesi auditor bermakna totalitas yang merupakan komitmen pribadi, sehingga kompensasi utama yang diharapkan dari pekerjaan adalah kepuasan rohani, baru kemudian materi. "Auditor bertanggung jawab untuk menjamin bahwa klienklien telah mengambil langkah-langkah yang dianggap perlu dalam memberitahukan pemakai laporan keuangan atas kesalahan-kesalahan laporan tersebut. Saya akan merasa sangat senang jika dapat memberi tahu klien tentang kekeliruan dalam penyajian laporan keuangan yang dibuatnya, disana kepuasan yang saya dapat adalah bisa mengedukasi klien, secara tidak langsung saya akan terus belajar dan belajar."

Erna mengatakan bahwa melalui profesi auditor ini, dirinya dapat mencurahkan dirinya lebih banyak untuk mengedukasi klien berdasarkan pengalaman dan hal-hal yang ia telah pelajari selama berkecimpung dalam profesi auditor. Sehingga harapan ke depan profesi auditor dapat menjadi jembatan utama dalam mengurangi expectation gap (kesenjangan) antara manajemen sebagai yang bertanggung jawab atas penyajian laporan keuangan dan para pengguna laporan keuangan sebagai pengambil keputusan. Pekerjaan auditor memberi arti yang penting kepada masyarakat terutama untuk mengetahui tingkat kepercayaan masyarakat terhadap laporan keuangan (Munidewi dan Pertiwi, 2016).

Aspek akuntabiltas yang tidak kalah penting selain motivasi dan pengabdian pada profesi adalah auditor dapat menyadari dirinya memiliki kewajiban sosial diharuskan memiliki pandangan tentang pentingnya peranan profesi auditor dan manfaat yang diperoleh masyarakat maupun professional karena adanya keberadaan diri auditor tersebut, selanjutnya disebut sebagai kewajiban sosial. Auditor memiliki kewajiban untuk memberikan yang terbaik bagi masyarakat, termasuk mengedukasi masyarakat tentang keberadaan auditor untuk masyarakat.

Perilaku profesional yang diisyaratkan dalam standar auditing menuntut auditor harus mempunyai sikap yang independen dalam melaksanakan setiap pekerjaannya disamping mempunyai integritas yang merupakan kualitas yang dapat menimbulkan kepercayaan masyarakat dan memberikan tatanan nilai bagi jasa auditor dan serta objektivitas yang merupakan suatu keyakinan atas kualitas dalam memberikan nilai bagi jasa auditor (Rahman, 2011).

Sejalan dengan apa yang disampaikan oleh Sita mengenai bagaimana ia sebagai seorang auditor dapat memberikan kontribusi ke masyarakat. "Peran saya sebagai auditor di dalam masyarakat adalah ketika ikut tergabung dalam organisasi di masyarakat, saya memberikan saran, kritik dan terjun langsung dalam proses penyusunan laporan keuangan, selain itu memberikan informasi mengenai kemungkinankemungkinan risiko yang akan dihadapi yang berkaitan dengan laporan keuangan."

Sebagai seorang auditor yang lahir dan tinggal di Bali dan memiliki keterikatan dengan masyarakat dan adatnya, Sita memanfaatkan momentum ini 
dengan terjun langsung ke masyarakat memberikan saran-saran untuk perbaikan organisasi masyarakat dan pemuda yang diikutinya, terkait laporan pertanggung jawaban suatu kegiatan dengan latar belakang pengalaman dan ilmu pengetahuan sebagai auditor kantor akuntan publik. Hal yang senada juga diungkapkan oleh Made, yang juga tergabung dalam organisasi pemuda di desa tempat asalnya. "Sebagai auditor, dalam masyarakat menurut saya mampu memberikan saran kepada masyarakat banjar maupun organisasi pemuda dalam membuat laporan pertanggungjawaban kegiatan, membuat $R A B$ kegiatan, dan segala hal yang ada hubungannya dengan laporan keuangan."

Kewajiban sosial auditor tidak hanya menyangkut tanggung jawabnya dalam penyelesaian audit suatu entitas atau klien yang sedang terikat kontrak dengan kantor akuntan publik tempat auditor tersebut bernaung, namun membantu masyarakat dalam memecahkan persoalan terkait penyajian laporan keuangan berupa laporan pertanggung jawaban kegiatan merupakan kewajiban profesi auditor agar masyarakat tidak terbelenggu dalam salah saji yang material yang disebabkan oleh kesengajaan (fraud) atau ketidaksengajaan.

Profesi auditor diharapkan oleh banyak orang untuk dapat meletakkan kepercayaan pada pemeriksaan dan pendapat yang diberikan sehingga profesionalisme menjadi tuntutan utama seseorang yang bekerja sebagai auditor eksternal (Kurniawanda, 2013). Hal ini juga diungkapkan oleh Erna. "Menurut saya, auditor bisa dibilang sebagai pihak kepercayaan masyarakat dalam hal ini investor dalam memastikan informasi yang andal dalam laporan keuangan. Jadi wajar saja rasanya jika masyarakat turut mengawasi hasi pekerjaan auditor, karena peran auditor di masyarakat menuntut profesi ini untuk selalu profesional, independen, serta taat pada etika dan aturan yang berlaku."

Berdasarkan pernyataan-pernyataan di atas yang merupakan hasil wawancara dengan auditor-auditor, peneliti berkesimpulan bahwa akuntabilitas auditor dipahami melalui pengalaman-pengalaman selama bekerja sebagai auditor dan kasus-kasus yang dihadapi oleh setiap klien memperkaya kemampuan auditor dalam penyelesaian masalah yang sedang dihadapi berkaitan dengan pekerjaan audit. Aspek-aspek akuntabilitas merupakan bekal penting untuk menjadi seorang auditor profesional.

Motivasi auditor terhadap profesinya dari petikan beberapa wawancara di atas masih terkait dengan penghasilan untuk membiayai hidup, artinya unsur intrinsik masih menjadi hal yang utama bagi auditor untuk dapat menjalankan tugasnya dalam audit, kemudian menjadi seorang auditor membuat auditor itu sendiri banyak memperoleh pengalaman khususnya untuk menghadapi berbagai macam karakteristik klien. Motivasi lainnya yang patut dimiliki oleh auditor adalah keinginan untuk memiliki pemahaman yang baik mengenai prosedur dalam audit dan menemukan potensi-potensi fraud dalam penyajian laporan keuangan.

Pemahaman Auditor tentang Akuntabilitas dari Perspektif Ajaran Karma Phala dilandasi Bhagawadgita, III. 14:
Annad bhavanti bhutani
Parjanyad annasambhavah
Yajnad bhavati parjanyo
Yajnah karma samudhavah
(Bhagawadgita, III. 14)
artinya:
Dari makanan mahluk menjelma
Dari hujan lahirnya makanan
Dari yadnya muncullah hujan
Dan yadnya lahir dari pekerjaan

Kutipan tersebut mengandung makna bahwa karmaphala berarti buah perbuatan. Setiap perbuatan akan mendatangkan hasil. Tiada satu pun di alam semesta ini akan luput dari hukum karma phala, karena setiap pekerjaan akan menampakkan hasil. Jika tidak ada sebab tidak akan mungkin ada hasil. Ini adalah hukum sebab akibat yang merupakan keyakinan yang sangat mendasar dalam ajaran agama Hindu. Hukum karma phala tak akan pernah melenceng dari sasarannya. Artinya, hasil akan selali datang pada penyebabnya, tanpa memandang latar belakang orang tersebut.

Akuntabilitas auditor juga terkandung makna bahwa dengan melakukan karya atau pekerjaan dengan sebaik-baiknya maka akan memberikan kontribusi yang besar bagi masyarakat. Hal ini sejalan dengan konsep ajaran hukum karma phala. Auditor kemudian meyakini bahwa ajaran karma phala sangat penting untuk selalu diingat dan dimplementasikan, seperti kutipan pernyataan berikut dari Sita. "Karma phala tentu saja ada hubungannya dengan pekerjaan yang saya lakukan, dengan ajaran tersebut saya percaya karma phala itu apabila pekerjaan yang saya lakukan baik maka hasil yang saya dapatkan baik, begitu pula sebaliknya. Saya memandang ajaran karma phala sebagai suatu pedoman dalam bertindak, dimana kita akan mampu menahan diri kita ketika kita ingin berbuat buruk 
dalam pekerjaan karena kita tahu bahwa hasil yang kita dapat adalah buruk. Selain itu ajaran ini menjadi pedoman dalam berperilaku sehingga saya sangat berhati-hati dalam melakukan sesuatu dan mengambil keputusan."

Ajaran karma phala ini diterapkan oleh Sita dalam melakukan tanggung jawabnya sebagai auditor. Dalam menjalankan tugasnya, auditor hendaknya sedari awal telah memikirkan konsekuensinya jika yang bersangkutan tidak menjalankan tanggung jawabnya sesuai dengan prosedur dan standar audit. Melalui ajaran karma phala yang melekat di setiap kehidupan umat di dunia, maka dapat menjadi pengingat khususnya profesi auditor untuk menjauhi perbuatan yang mengandung moral hazard.

Keyakinan yang sama terhadap keberadaan hukum karma phala juga diungkapkan oleh Anton.

"Saya memandang ajaran karma phala dalam lingkungan kerja karena ajaran tersebut menjadi dasar atau pedoman saya dalam berperilaku, hal itu membuat saya lebih berhati-hati dalam bekerja maupun mengambil keputusan."

Sejalan dengan pendapat dari Sita dan Anton, ajaran hukum karma phala juga sangat melekat erat dalam kehidupan Erna sebagai auditor.

"Ajaran karma phala sangat berkaitan erat dengan pekerjaan saya sebagai auditor. Jika kita bekerja dengan jujur, teliti, disiplin, bertanggung jawab maka hasil yang kita dapatkan tentu lebih baik. Misalnya klien akan senang dan puas dengan kinerja kita. Banyak klien baru yang akan datang karena kinerja kita yang bagus."

Erna percaya bahwa dengan bekerja secara jujur, disiplin, bertanggung jawab maka hal-hal tersebut dapat meningkatkan kinerja auditor. Implementasi ajaran karma phala dengan berbuat baik akan mendatangkan sesuatu yang baik pula, tergambar dari apresiasi klien terhadap kinerja auditor dan secara tidak langsung apa yang telah kita perbuat tersebut akan terdengar oleh calon-calon klien lain yang ingin menggunakan jasa kita.

Karma phala akan selalu melekat pada diri manusia, tak seorang pun dapat melepaskan diri dari hukum tersebut. Auditor yang menjadi informan dalam penelitian ini pun yakin terhadap keberadaan hukum karma phala, mereka menjadikan ajaran ini sebagai pedoman dalam berpikir, berbuat dan berucap dalam menjalankan tanggung jawab sebagai auditor. Apa yang diterapkan auditor tersebut diwakilkan oleh salah satu kutipan dalam kitab Sarasamuccaya berikut.

Yuvaiva dharmamasilah syadanityam khalu jivitam Ko hi janati kadyadya mrtyusena patisyati (Sarasamuccaya. 31)
Matangnyan pengpongan wenangta, mangken rare ta pwa kitan lekasakena agawe dharmasadhana, apan anitya iking hurip, syapa kari wruha ri tekaning pati, syapa mangwruhan ri tekaning patinya wih.

Artinya:

Karena itu, pergunakanlah sebaik-baiknya kemampuan yang ada sekarang selama anda masih muda, hendaklah anda lekas-lekas melakukan pekerjaan yang bersandarkan dharma, sebab hidup ini tidak tetap, siapa gerangan akan tahu tentang datangnya maut, siapa pula akan memberitahukan datangnya maut itu.

Akuntabilitas auditor dalam perspektif ajaran hukum karma phala ini seharusnya dapat diimplementasikan oleh semua profesi auditor, tidak mengkhusus bagi auditor yang merupakan umat Hindu. Hukum karma phala bersifat abadi, artinya sudah ada sejak mulai penciptaan alam semesta ini dan tetap berlaku sampai alam semesta ini mengalami kiamat (pralaya). Hal lain tentang hukum karma phala adalah bersifat universal, artinya berlaku bukan untuk manusia tetapi juga untuk mahluk-mahluk seisi alam semesta, berlaku sejak jaman penciptaan, jaman sekarang dan jaman yang akan datang, bersifat sempurna dan adil, dan tidak ada pengecualian terhadap siapapun.

Gambaran mengenai aspek-aspek akuntabilitas auditor dan keterkaitannya dengan ajaran hukum karma phala dapat dilihat pada Gambar 2.

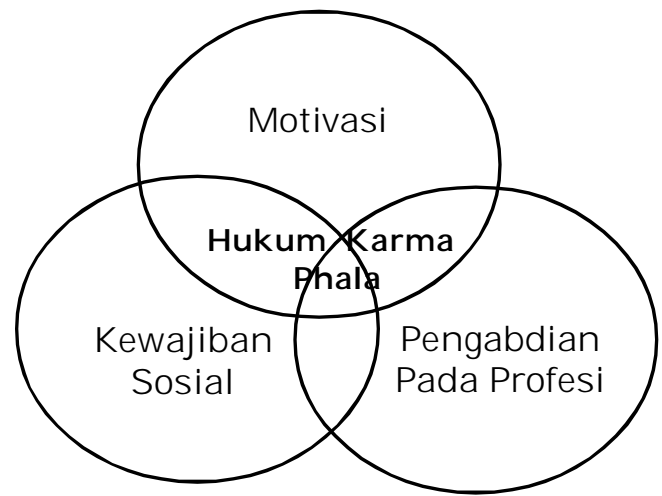

\section{Gambar 2. Akuntabilitas Auditor dalam Perspektif Karma Phala}

Sumber: Data diolah, 2016

Sesungguhnya hukum karma phala ini telah masuk ke dalam aspek-aspek akuntabilitas auditor yakni motivasi, kewajiban sosial dan pengabdian profesi. Keyakinan auditor terhadap hasil auditnya tidak hanya dari kepatuhan terhadap kode etik profesi, standar audit dan peraturan perundang-undangan 
yang berlaku, namun keyakinan terhadap perbuatan dan hasil yang nantinya didapatkan seperti ajaran karmaphala (hukum sebab akibat) juga dapat menjadi pedoman dalam menjalankan profesi auditor. Jika auditor dapat mengkombinasikan keyakinan adanya hukum sebab akibat dan peraturan serta kode etik profesi tersebut maka hasil audit akan menjadi berkualitas dan laporan audit yang dihasilkan dapat menghasilkan informasi yang relevan bagi pengambil keputusan.

Hanya saja ajaran karma phala ini dapat ditekankan melalui penegasan peran auditor di masyarakat dan bagi profesinya yang dapat dicantumkan atau diberikan melalui manual Standar Pengendalian Mutu (SPM) serta Standard Operating Procedure dalam setiap prosedur audit untuk auditor. Hal ini dapat dilakukan untuk mengurangi kasus-kasus penyalahgunaan tanggung jawab auditor kedepannya. Kasus-kasus terkait profesi akuntan seperti kasus Enron, yang melibatkan Arthur Andersen atau kasus Worldcom, serta kasus yang terjadi di Indonesia dapat menjadi pembelajaran bahwa hukum karma phala itu memang ada, dimana pada akhirnya akuntan atau auditor yang terlibat di dalamnya mendapatkan hukuman sesuai dengan perbuatannya.

\section{SIMPULAN}

Melalui penelitian ini, kesimpulan yang dapat diambil adalah dalam menjalankan profesi auditor, auditor terikat dalam akuntabilitas dalam proses audit. Akuntabilitas ini memiki tiga aspek-aspek yakni motivasi, kewajiban sosial dan pengabdian pada profesi yang harus disadari oleh seseorang yang memutuskan untuk berprofesi sebagai auditor eksternal. Implementasi ketiga aspek akuntabilitas ini dapat menghasilkan kualitas hasil audit. Dalam ajaran agama Hindu, kita mengenal adanya keyakinan terhadap hukum sebab akibat (karma phala) yang bersifat abadi dan universal.

Apabila melihat dari perspektif atau sudut pandang ajaran hukum karma phala ini, ajaran ini ternyata telah melekat dalam aspek-aspek akuntabilitas auditor. Hanya, penekanan terhadap ajaran karma phala ini harus lebih ditingkatkan melalui penyadaran-penyadaran peran auditor dalam kehidupan masyarakat. Kantor akuntan publik melalui partnernya, dapat menambahkan akuntabilitas auditor serta sebab dan akibat apabila auditor tidak bekerja sesuai dengan kode etik profesi dan standar audit. Etika profesi yang menjadi salah satu subjek di bangku perkuliahan dapat menjadi sarana untuk memberikan pemahaman mengenai tanggung jawab auditor serta dengan memberikan penekanan melalui kasus-kasus yang terkait dengan penyalahgunaan tanggung jawab profesi dapat membuat calon-calon auditor berpikir jika melakukan perbuatan baik maka hasilnya akan baik pula, namun sebaliknya jika berbuat buruk maka hasilnya akan buruk pula dalam menjalankan tugasnya nanti sebagai auditor.

Penelitian ini dapat memberikan implikasi terhadap praktik akuntan publik untuk lebih sering mengingatkan auditornya agar mehamami perannya di masyarakat, menjalankan prosedur audit sesuai dengan standar audit, membuat kertas kerja, mengedukasi klien mengenai laporan keuangan dan peran audit itu sendiri, mengungkap apabila ada indikasi kecurangan yang berkaitan dengan penyajian laporan keuangan. Penelitian ini juga dapat memberikan saran bagi penyusun standar agar lebih memberi gambaran mengenai konsekuensi apabila auditor tidak melaksanakan tanggung jawabnya sesuai dengan standar, dengan mengambil konsep ajaran hukum karma phala ini.

Karakter seorang auditor tidak hanya terbangun dari jenjang pendidikan yang dilaluinya serta pengalaman yang dimilikinya. Namun karakter seorang auditor dapat terbangun dari nilai-nilai atau kearifan lokal yang ditanamkan sejak dini melalui keluarga. Hal ini menjadi keunikan dalam penelitian ini, dimana peneliti menggunakan ajaran karma phala untuk memberikan gambaran kepada auditor dalam membangun karakternya, sehingga kualitas audit dapat terwujud, dan kepercayaan masyarakat meningkat terhadap peran auditor.

Keterbatasan tidak luput dari penelitian ini. Penelitian ini hanya menggunakan informan yang merupakan junior auditor dari sebuah kantor akuntan publik. Penelitian berikutnya dapat melihat dari sudut pandang partner (pimpinan KAP), dan senior auditor terhadap akuntabilitas, karena peneliti yakin bahwa semakin lama seseorang berkecimpung dalam praktik audit eksternal maka sudut pandang terhadap akuntabilitas tersebut akan semakin dalam dipahami. Dikarenakan hasil dari perbuatan (karma phala) tersebut tidak dapat ditentukan oleh manusia, maka penelitian ini perlu dilakukan lebih lama untuk dapat mengetahui apa yang dirasakan oleh auditor ketika telah selesai menjalankan tanggung jawabnya.

\section{REFERENSI}

Ghony, M. D., \& Almanshur, F. (2012). Metodologi Penelitian Kualitatif. Ar-Ruzz Media: Jogjakarta. Ilmiyati, F., \& Suhardjo, Y. (2012). Pengaruh Akuntabilitas dan Kompetensi Auditor terhadap 
Kualitas Audit (Studi Empiris pada Kantor Akuntan Publik di Semarang). JURAKSI, 1(1).

Kajeng, I. N. (1997). Sarasamusccaya. Jakarta: Hanuman Sakti.

Kurniawanda, A. M. (2013). Pengaruh Profesionalisme Auditor dan Etika Profesi terhadap Pertimbangan Tingkat Materialitas. EJurnal Binar Akuntansi, 2(1).

Lunenburg, Fred. C. (2011). Expectancy Theory of Motivation: Motivating by Altering Expectations. International Journal of Management, Business and Administration, 15(1).

Mardisar, Diani, \& Ria Nelly Sari. (2007). Pengaruh Akuntabilitas dan Pengetahuan terhadap Kualitas Hasil Kerja Auditor. SNA X Makassar. AUEP-11.

Messier, W. F., \& Quilliam, W. (1992). The effect of accountability on judgement: development of hypotheses for auditing. Auditing: A Journal of Practice and Theory, 11, 123-151.

Miles, M. B., \& Huberman, A. M. (1984). Qualitative Data Analysis: A Source Book of New Methods. Beverly Hills: Sage Publication.
Munidewi, Budhananda, I. A., \& Pertiwi, I Dewa Ayu Eka. (2016). Menjembatani Fenomena Expectation Gap: Pemahaman Pengguna Laporan Keuangan dan Refleksi Diri Auditor. Jurnal Riset Akuntansi, 6(1).

Nugrahaningsih. (2005). Analisis Perbedaan Perilaku Etis Auditor di KAP dalam Etika Profesi (Studi terhadap Peran Faktor-faktor Individual: Locus of Control, Lama Pengalaman Kerja, Gender dan Equity Sensitivity). Simposium Nasional Akuntansi VIII Solo.

Pudja, I.G., \& Sudharta, T. (2004). Manawa Dharmasastra. Surabaya: Paramitha.

Rahman, F. (2011). Peran Manajemen dan Tanggung Jawab Auditor dalam Mendeteksi Kecurangan Laporan Keuangan. Jurnal Eksis, 7(2).

Robbins, Stephen P., \& Timothy A. Judge. (2008). Perilaku Organisasi Edisi ke-12, Jakarta: Salemba Empat.

Sukoharsono, Eko G. (1998). Accounting in a New History: A Disiplinary Power and Knowledge of Accounting. International Journal of Accounting and Bussiness Society, 6(2). 